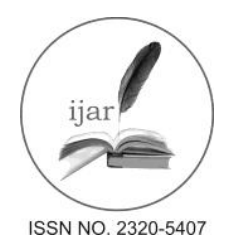

\section{Journal homepage:http://www.journalijar.com}

Journal DOI: 10.21474/IJAR01

\section{RESEARCH ARTICLE}

\title{
SLEEP QUALITY IN PREGNANCY AND NURSING INTERVENTIONS FOR IMPROVING THE SLEEP QUALITY.
}

Semiha Aydin Ozkan ${ }^{1}$ and Gülay Rathfisch ${ }^{2}$.

1. Department of Midwifery, School of Health Science, Adiyaman University, Adiyaman, Turkey.

2. Department of Women's health and diseases nursing, Florence Nightingale Nursing Faculty, Istanbul University, Istanbul, Turkey.

\section{Manuscript Info}

Manuscript History:

Received: 12 May 2016

Final Accepted: 16 June 2016

Published Online: July 2016

Key words:

*Corresponding Author

Semiha Aydin Ozkan.

\begin{abstract}
During the childbearing phase of life, a woman's sleep can be profoundly altered, with increased risk for physical and mental health problems. Poor sleep can adversely affect labor and delivery, lead to poor maternal infant interactions or poor relationships with other adults, and even affect the infant's growth and development. Hormonal alterations during early pregnancy, enlargement of the fetus during late pregnancy, and a newborn with random patterns of sleeping and feeding contribute to her disrupted sleep. This chapter briefly reviews normal physiological and anatomical changes that occur during pregnancy and discusses common sleep problems that can occur during pregnancy. Throughout this review chapter, the nurses' role in sleep promotion is discussed in relation to sleep hygiene behaviors that can be adapted for pregnant women.
\end{abstract}

Copy Right, IJAR, 2013,. All rights reserved.

\section{Introduction:-}

Pregnancy is one of the most important events in a woman's life she has experienced. Although pregnancy is a natural event, it brings along many physiological, psychological and social changes. Among these changes, in terms of affecting the quality of life and the pregnancy process, sleep is an important factor (Yanıkkerem, 2006).

Sleep is one of the essential daily life activities of individual and it is a concept that has physiological, psychological and social aspects. Kaynak (2003 p.128) stated that sleep is effective in resting the body and preparing for the next day, growth, regeneration of cells, repairing organisms, protection of memory and programming genetic memory. Besides, it was stated that sleep has a role to learn information and to make it permanent, particularly in some living creatures to adapt environment and protection from dangers (Kaynak, 2003 p.128).

Today, the sleep quality is one of the concepts that are emphasized with importance. After wake up, to feel fit, in form and ready for a new day for individual is defined as sleep quality. Sleep quality; also includes quantitative aspects of sleep such as sleep latency (duration of falling asleep), sleep duration and number of waking up in one night and more subjective aspects such as the depth and relaxing of sleep (Kaynak, 2003 p.128).

Sleep quality is affected by many physical, psychological and environmental factors. These factors which affect the sleep quality are consisted of age (Kiper and Sunal 2009; Hedman et al., 2002; Worth et al. 2002), gender (Dzaja et al., 2015), education (Tsai et al., 2011; Kiper and Sunal, 2008), employment status (Tsai et al., 2011; Kiper and Sunal, 2009), the number of children (Moline et al., 2003; Signal, 2007; Naud, 2010), usage of tea and coffee, smoking (Kaneita et al., 2005; Ohayon et al., 2001), BMI (Maasilta, 2001), doing exercise status (Özgen, 2001), health/disease status (Taşkıran, 2009) and drugs that are used (Özgen, 2001).

Hormonal and physical changes during pregnancy result in changes at sleep pattern and sleep quality (Sloan, 2008): increasing breathing problem because of the pressure on diaphragm from growing fetus, nocturia, back pain, leg 
cramps, restless leg syndrome (RLS)can be counted in these changes (Sharma and Franco, 2004). Wilson et al.(2011) indicated that, in his study with pregnant women who are going through first and third trimester of pregnancy and nonpregnant women, sleeping activities of pregnant women worse than nonpregnant women, wake up more frequently during sleep, NREM state 4 lasts shorter and state 1 lasts longer and REM sleep last for only few minutes. For first trimester pregnant women, it has seen that, comparing to nonpregnant women, their sleep affected less, night wake up count has increased, and NREM state 4 lasts shorter.

During pregnancy, average sleep duration around 7-8 hours, when compared to before pregnancy, average sleep duration has increased about 1 hour. Sleep problems start to increase in the first trimester of the pregnancy, and reach peak in the third trimester. (Pollak et al., 2010, p.179). Physical complaints which cause sleep problems are summarized in Table 1.

Table 1:-physical complaints which cause sleep disruption during pregnancy.

\begin{tabular}{|l|l|}
\hline Trimester & Trimester Symptoms Associated with Sleep Disruption \\
\hline First trimester & Lessthan 5\% havejointpain, nightmares, oranxiety. \\
\hline & $12 \%-15 \%$ reportdisturbedsleepduetonausea, vomiting, orbackache. \\
\hline & About $20 \%$ begintoexperiencesuddenawakeningfrompainfullegcramps. \\
\hline Second trimester & $50 \%-52 \%$ reportfrequentnocturnalvoiding. \\
\hline & About $20 \%$ begintoreportthatfetalmovementsandheartburndisruptsleep. \\
\hline Third trimester & $30 \%$ report a newonset of snoringduringpregnancy \\
\hline & Lessthan 5\% havenightmaresoranxiety. \\
\hline & About 5\% reportawakeningfromfetalmovement. \\
\hline & $19 \%-25 \%$ experiencerestlesslegssyndrome. \\
\hline & $20 \%-25 \%$ havejointpain. \\
\hline & $25 \%$ sufferfromheartburnoresophagealreflux. \\
\hline & $45 \%-50 \%$ reportfrequentnocturnalvoiding. \\
\hline & $75 \%$ experience awakenings from leg cramps. \\
\hline
\end{tabular}

(Lee KA. (2011). Sleep Promotion in the childbearing family. In (Ed). Redeker N., McEnany GP. Sleep disorders and sleep promotion in nursing practice. Springer Publishing Company. p263)

In the prevalence studies which aim to determine the sleeping problem of pregnant women; Sharma and Franco (2004) stated that 97\%, Hutchison et al. (2002) 71,5\%, Naud et al. 56\% of the pregnant women has been living through sleep problems in the third trimester of pregnancy. In Turkey, Taşkıran (2009) stated these sleep problem rate as $86 \%$ and Özkan (2013) stated as $89.3 \%$.

In the studies of sleep quality, it has seen that bad sleeping quality has negative effects on birth action and fetal health.It has been determined that, risk of preterm action has increased in pregnant women, their birth type mainly cesarean, and vaginal birth action is getting longer. Moreover, it determined that, bad sleep quality's neonatal health effects are low neonatal apgar score and neonatal birth weight (Lee and Gay, 2004; Naghi et al., 2011; Zafarghandi et al., 2011; Micheli et al., 2011). Okun and friends (2011) stated in his studies that, during 14-16 weeks, bad sleep quality increases preterm action risk by 1,25 times, during 30-32 weeks, preterm action risk increases by 1 , 18 times and Michelli and friends (2011) stated that during third trimester, bad sleeping quality increases preterm action risk by 1,7 times. In addition, in another study, has found that, prenatal sleeping disorders trigger postpartum depression development (Wilkie, 1992).

The prevalence of symptoms associated with disrupted sleep by trimester is summarized in Table 1. In general, these are common complaints that increase in frequency or severity as gestation increases, and many strategies have been described in the literature to cope with these symptoms. Very little research has been done to provide the definitive evidence for implementing these strategies, but most are comfort measures that are nonpharmacologic and easily implemented and discarded if not effective (Lee, 2011. p263).

\section{Nursing attempts for improving the sleep quality in pregnancy:-}


Sleeping, which is a basic human need, has been talked over by many theoretician nurse. Maslow who defined basic human needs, included sleep in physiological needs, theoretician nurses Roper, Logan, Tierney included in 12 living action, Henderson included in 14 basic requirements, Abdellah included in 21 nursery problems and Gordon included sleeping in functional health patterns. It is expected that, nurses who approach the patient with holistic view, should approach the patient with all aspects. Henderson defined nursing function for sleep need as "helping the patient in order to get sleep and rest". "Disorder of sleeping pattern" is defined as a situation which causes disorder in resting patterns in terms of quality and quantity or a situation that affects mode of living. It consist a place in nursing definition which is stated by NANDA (North American Nursing Diagnosis Association) and remains as an important nursing definition. (Maslow, 1943 p. 382; Roperet al., 1996 p. 448; Henderson, 1978; Abdellah, 1957; Gordon, 1982 p. 4; Carpenito, 1999 p. 344).

Nurses play an important role in evaluation of pregnant women's sleep needs, determination of the sleep quality, definition of the issues which cause sleeping problems, and keeping pregnant women relaxed. In order to approach pregnant women with holistic view, nurses must be able to define the factors which cause sleeping problems in pregnant women, must determine the attempts in order to raise sleep quality and it has been expected that, they must put in practice these attempts according to the situation (Potter and Perry, 2009 p.1037).

In order to plan the attempts which are aimed to solve pregnant women's sleeping problems, they must evaluate the characteristics of sleep during pregnancy, bedtime, sleep habits and physical complaints, which can affect sleep quality, according to trimesters. Knowing the sleep physiology during pregnancy and factors which cause sleep disorder will ease the evaluation. In this evaluation, a sleep definition must be done, and it must includes the topics which are before pregnancy sleeping pattern, and the changes which are occurred in sleeping pattern during pregnancy, sleeping environment, general health situation, medical background, general life changes that occurred during pregnancy. In order to solve the pregnant women's sleeping problem and increase the sleep quality, non pharmacological treatment methods which nurses can put in practice independently, must be used (Potter and Perry, 2009 p.1037).

As non pharmacological treatments approaches to sleep disorders during pregnancy, stimulus control therapy, sleep restriction therapy, sleep hygiene and relaxation exercise are suggested (Lee, 2011 p.264).

\section{Stimulus Control Therapy:-}

Stimulus control therapy aims to control environmental (bed and bedroom) stimulus, bedtime stimulus and the habits which are not compatible with the sleep. Stimulus control therapy mainly used in patients who are having difficulties with start sleeping and continuing it. It is generally preferred and seen as a simple procedure. Although, in order to increase patients' sleep and get the wanted result, weekly tracking needed for a few weeks (Y1lmaz andTuncel, 2014).

\section{Sleep Restriction Therapy:-}

In basic, by restricting the time which is spending in the bed until to sleep duration, it consists of progressive increase. To increase the total sleeping time, patient stays in the bed longer. At night, before the sleepy mood, patient goes to bed, and in the morning, although patient is awake, continues to stay in the bed. As a result of this application, sleep withdrawal appears and it fastens passing through sleep. As continuity of sleep increases, less shattered more complete sleep and state 3-4 sleep increases and provides deep sleep. In addition to sleep restriction therapy, a joint sleeping plan with stimulus control therapy is considered be more efficient (Y1lmaz andTuncel, 2014).

\section{Sleep Hygiene:-}

Sleep hygiene aims to increase the knowledge and awareness about healthy sleep habits and environmental factors and intended to develop new healthy sleep hygiene habits. With this aim, person gets informed about life styles and environmental factors and for a better sleep, nurses make suggestion (Y1lmaz andTuncel, 2014).

The sleep hygiene strategies described in Table 2 are all categorized as comfort measures to reduce symptoms and promote sleep during pregnancy. They are organized using the acronym, B.E.T.T.E.R to help patients remember to think about their Bedroom environment, what they Eat and drink, how to reduce Tension, be aware of the Time they spend in bed, the importance of regular Exercise, and keeping a consistent circadian Rhythm. These are all useful strategies for promoting sleep in any adult, and can be reinforced for the woman's entire family Despite the best of 
sleep hygiene practices, pregnancy can place women at risk for specific sleep disorders. If the nursing assessment reveals that daytime sleepiness is occurring despite healthy sleep hygiene behaviors, the potential for a sleep disorder must be investigated for the health and safety of the mother and fetus. (Lee, 2011 p. 264)

Table 2:-In order to increase sleep quality, B.E.T.T.E.R. strategies

\begin{tabular}{|c|c|}
\hline \multirow[t]{7}{*}{ Bedroom } & Make bedroom dark, cool, safe, and comfortable. \\
\hline & Use night light in the bathroom to decrease arousal time. \\
\hline & Use white noise machine or fan to mask noise from traffic or bed partner. \\
\hline & Use pillows between the knees, under abdomen and behind the back for comfort. \\
\hline & $\begin{array}{l}\text { Sleep side-lying, preferably left lateral position, to improve blood flow to fetus and improve } \\
\text { maternal renal function. }\end{array}$ \\
\hline & Elevate head of bed to reduce heartburn and snoring. \\
\hline & Use nasal dilator strips or saline nasal washes to relieve nasal congestion. \\
\hline \multirow[t]{9}{*}{ Eating } & Drink lots of water during the day, but cut down before bedtime to reduce nocturia. \\
\hline & Keep dry crackers at the bedside to ease morning or evening nausea. \\
\hline & Eat a balanced diet (include magnesium, potassium, calcium). \\
\hline & Rather than hot chocolate in the evening, consider drinking Ovaltine with hot milk. \\
\hline & Take vitamin $\mathrm{C}$ and eliminate caffeine to increase folate absorption from food. \\
\hline & Avoid carbonated beverages to reduce risk of leg cramps. \\
\hline & Take prenatal vitamins with iron and folate to reduce risk of restless legs syndrome. \\
\hline & Avoid caffeine, spicy, acidic, and fried foods to reduce heartburn. \\
\hline & Eat small meals during the day to reduce heartburn. \\
\hline \multirow[t]{4}{*}{ Tension } & Practice relaxation techniques to reduce tension. \\
\hline & Use massage, local heat, and pillow support for low back pain. \\
\hline & Consider drinking non-caffeinated hot tea in the evening. \\
\hline & Consider the sedative effects of lavender pillows or bubble bath in the evening. \\
\hline \multirow[t]{4}{*}{ Time in Bed } & Plan a regular sleep-wake schedule, prioritize sleep as "sleeping for two." \\
\hline & $\begin{array}{l}\text { Extend your time in bed by } 10 \text { minutes each month of pregnancy, so there is at least } 8 \text { hours in } \\
\text { bed to get a minimumof } 7 \text { hours of sleep during the last month of pregnancy. }\end{array}$ \\
\hline & Consider a nap during the day unless you have problems falling asleep at bedtime. \\
\hline & Stay in bed only when sleepy. \\
\hline \multirow[t]{2}{*}{ Exercise } & Exercise daily to control weight gain, improve circulation, reduce tension and stress. \\
\hline & Consider a yoga class with poses and breathing specific to pregnancy. \\
\hline \multirow[t]{4}{*}{ Rhythm } & Get daylight exposure every day. \\
\hline & Eat meals and snacks at consistent times. \\
\hline & Have a consistent nightly bedtime and morning wake time. \\
\hline & Get up out of bed at the same time every morning. \\
\hline
\end{tabular}

(Lee KA. (2011). Sleep Promotion in the childbearing family. In (Ed). Redeker N., McEnany GP. Sleep disorders and sleep promotion in nursing practice. Springer Publishing Company. p263)

\section{Relaxation exercises:-}

Anxiety and tension comes out with lack of sleep and it is a factor that has a continuity effect. The aim of relaxing method is to lower alertness and performance anxiety which occurs during bedtime or night awaking. Techniques like progressive muscle relaxation techniques, autogenetic education which oriented at physical alertness can be used, likewise, passive methods, such as concentrating on body, relaxing visual techniques, meditation, stopping thoughts methods also in use (Yilmaz and Tuncel, 2014).

In 1971, relaxation exercises appeared in literature with the usage of systematic relaxation education as to be nursing approach to open heart surgery patients by Aiken and Henrichs. Following years, relaxation exercise, as being independent function of nurses, has used in many different fields of nursing applications. Since the following years after this study, nurse researchers, used relaxation exercises in the nursing definitions of sleep problems, anxiety, pain, ineffective breathing, ineffective coping.(Shue et al., 2003; Kuzeyli, 2002: Wilk and Turkoski, 2001; Cheung et al., 2003; Aiken and Henrichs, 1971; Beddoe et al, 2010; Yıldızeli-Topçu and Yıldız-Fındık, 2012) 
As a result, common sleeping problems of pregnant women, sleeping problem has bad results on maternal and fetal health, because of these results, in nursing applications, sleeping problems is one of the important nursing definitions. For sleep disorders during pregnancy, as a non pharmacological treatment approach, stimulus control therapy, sleep restriction therapy, sleep hygiene, and relaxation exercises make passing sleep easier, and support sleep continuity. Because of these benefits, in nursing applications, these are in a widespread usage.

Kaynaklar:-

1. Abdellah, F.G. (1957).Methods of IdentifyingCovertAspects of NursingProblems AKeytoImprovedClinicalTeaching. NursingResearch, 6(1), 4-23.

2. Aiken, L.H. ve Henrichs, T.F. (1971).SystematicRelaxation As A NursingInterventionTechniqueWith Open HeartSurgeryPatients. NursingResearch, 20(3),212-217.

3. Beddoe, A.E., Lee, K.A., Weiss, S.J., Kennedy, H.P., Yan, C.P. (2010).Effects of Mindful Yoga on Sleep in PregnantWomen: A Pilot Study. BiologicalResearchforNursing, 11(4),363-370.

4. Carpenito, L.J. (1999).Handbook of NursingDiagnosis. Tercüme: Erdemir, F. Hemşirelik Tanıları El Kitabı. İstanbul: Nobel Tip Kitabevleri, 344-348.

5. Cheung, Y.L.,Molassiotis, A. ve Chang, A.M. (2003).TheEffect Of ProgressiveMuscleRelaxation Training On AnxietyAndQuality Of Life AfterStomaSurgeryInColorectalCancerPatients. Psycho-Oncology;12,254-266.

6. Dzaja, A.,Arber, S., Hislop, J., Kerkhofs, M., Kopp, C., Pollmacher, T. ve ark. (2005). Women'sSleep in HealthandDisease. Journal of PsychiatricResearch, 39, 55-76.

7. Gordon, M. (1982).FunctionalHealthPaterns, NursingDiagnosisProcessandAplication. New York: McGrawHillBook Comp; 4 .

8. Hedman, C.,Pohjasvaaara, T., Tolonen, U., Suhonen-Malm, A.S. ve Myllylä, V.V. (2002).Effects of Pregnancy on MothersSleep. SleepMedicine. 3(1), 37-42.

9. Henderson, V. (1978). TheConcept of Nursing. Journal of Advanced Nursing 30th AnniversaryIssue, 3, 113130 .

10. Hutchison, B.L., Stone, P.R., McCowan, L., Stewart, A.W., Thompson, J. ve Mitchell, E. (2012). A Postal Survey of MaternalSleep in LatePregnancy. BMC PregnancyandChildbirth, 12(144), 2-7.

11. Kaneita, Y.,Ohida, T., Takemura, S., Sone, T., Suzuki, K., Miyake, T. ve ark. (2005). Relation of SmokingandDrinkingtoSleepDisturbanceAmongJapanesePregnantWomen. Preventive Medicine,41, 877-882.

12. Kaynak, H. (2003). Uyku. Uyuyamamak mı Uyanamamak mı. İstanbul: Doğan Kitapçılık.

13. Kiper, S. ve Sunal, N. (2009). RomatoidArtritli Hastalarda Uyku Kalitesinin Değerlendirilmesi. Kocatepe Tıp Dergisi, 10, 33-39.

14. Kuzeyli Yıldırım Y. (2002). Diyaliz Hastalarında Progresif Gevşeme Yöntemlerinin Kaygı Düzeyi ve Yaşam Kalitesine Olan Etkisinin İncelenmesi. Yüksek Lisans Tezi. Ege Üniversitesi Sağlık Bilimleri Enstitüsü İç Hastalıkları Hemşireliği Anabilim Dalı, İzmir.

15. Lee, K.A. (2011).SleepPromotion in theChildbearing Family. In N. Redeker, G.P. McEnany (Ed). SleepDisordersandSleepPromotion in NursingPractice. New York. Springer Publishing Company.

16. Lee, K.A. ve Gay, C.L. (2004). Sleep in LatePregnancyPredictsLength of LaborandType of Delivery. AmericanJournal of ObstetricsGynecologly. 191,2041-2046.

17. Maasilta, P.,Bachour, A., Teramo, K., Polo, O. ve Laitinen, L.A. (2001).SleeprelatedDisorderedBreathingDuringPregnancy in ObeseWomen. Chest,120(5),1448-1454

18. Maslow, A. H. (1943). A Theory of Human Motivation. PsychologicalReview, 50(4), 370-396.

19. Micheli, K.,Komninos, I., Bagkeris, E.,Roumeliotaki, T., Koutis, A., Kogevinas M. ve ark. (2011).SleepPatterns in LatePregnancyand Risk of PretermBirthandFetalGrowthRestriction.Epidemiology, 22, 738-744.

20. Moline, M.,Broch, L., ve Zak, R. (2006). TheImpact of Life Cycle on Sleep in Women. İçinde H.P. Attarian (Ed).SleepDisorders in Women A Guide toPractical Management. Totowa, New Jersey, HumanaPressInc.

21. Naghi, I.,Keypour, F., Ahari, S.B., Tavalai, S.A. ve Khak, M. (2011).SleepDisturbance in LatePregnancyandTypeandDuration of Labour. Journal of ObstetricsGynaecologly, 31(6), 489-91.

22. Naud, K.,Ouellet, A., Brown, C., Pasquier, J.C. ve Moutquin, J.M. (2010). Is SleepDisturbed in Pregnancy? Journal of ObstetricsandGynaecologyCanada, 32(1),28-34.

23. Ohayon M.M.,Li, K.K. ve Guilleminault, C. (2001). Risk FactorsforsleepBruxism in the General Population, Chest, 119(1): 53-69

24. Okun, M.L., Schetter, C.D., Glynn, L.M. (2011).PoorSleepQuality is AssociatedwithPretermBirth. Sleep, 34(11), 1493-1498.

25. Özgen, F. (2001).Uyku ve Uyku Bozuklukları. Psikiyatri Dünyası, 5, 41-48 
26. Özkan, Z. (2013). Gebelikte Uyku Kalitesinin Travay Süresi ve Doğum Ağrısı Üzerine Etkisi. Yüksek Lisans Tezi. İstanbul Üniversitesi Sağlık Bilimleri Enstitüsü, İstanbul

27. Pollak, C.P.,Thorpy, M.J., Yager, J. (2010).The Encyclopedia of SleepandSleepDisorders. (3.th Ed.).Infobase Publishing

28. Potter, P.A. ve Perry, A.G. (2009).Sleep, Fundamentals of Nursing, (7th Ed.). Philadelphia, MosbyElsevier.

29. Roper, N.,Logan, W.W. ve Tierney, A. J. (1996).TheElements of Nursing: A Model forNursingbased on a Model of Living. (4th Ed.). New York: Churchill Livingston; 416-452.

30. Sharma, S.,Franco, R. (2004).SleepandItsDiorders in Pregnancy. Wisconsin Medical Journal.103:48-51.

31. Shue, S.,Irvin, B.L., Lin, H.S. ve Mar, C.L. (2003).Effect of ProgressiveMuscleRelexation on Blood PressureandPsychosocialStatusforClientswithEssentialHypertension in Taiwan. HolisticNursingPractice, 17(1),41-47.

32. Signal, T.L.,Gander, P.H., Sangelli, M.R., Travier, N., Firestone, R.T., Tuohy, J.F. (2007).SleepDurationandQuality in HealthyNulliparousandMultiparousWomenacrossPregnancyandPostpartum. The Australian and New ZealandJournal of Obstetrics andGynaecology, 47(1),16-22.

33. Sloan, E. P. (2008). Sleep Disruption During Pregnancy. Sleep Medicine Clinics, 3, 73-80.

34. Taşkıran, N. (2011).Gebelik ve Uyku Kalitesi. Türk Jinekoloji ve Obstetrik Derneği Dergisi, 8(3),181-187.

35. Tsai, S.Y.,Kuo, L.T., Lai, Y.H. ve Lee, C.N.(2011).Factors Associated with Sleep Quality in PregnantWomen: A Prospective Observational Study. Nursing Research ,60(6),405-412. Erişim 22.08.2013

36. Wilk, C.,Turkoski, B. (2001).ProgressiveMuscleRelaxation in CardiacRehabilitation: A Pilot Study. Rehabilitation Nursing,26(6),238-242.

37. Wilkie, G.,Shapiro, C.M. (1992).Sleepdeprivationandthepostnatalblues. Journal of Psychosomatic Research. 36,309-316.

38. Wilson, D.L.,Barnes, M., Ellett, L., Permezel, M., Jackson, M. ve Crowe, S.F. (2011).DecreasedSleepEfficiency, Increased Wake afterSleeponsetandIncreasedCorticalArousals in LatePregnancy. Australianand New ZealandJournal of ObstetricsandGynaecology. 51(1),38-46.

39. Worth, J.,Onyeije, C.I., Ferber, A., Pondo, J.S. ve Divon, M.Y. (2002). TheAssociationbetweenFetalandMaternalSleepPatterns in Third-trimesterPregnancies. AmericanJournal of Obstetricsand Gynecology,186(5),924-925.

40. Yanıkkerem, U.E., Altıparmak, S., Karadeniz, G. (2006).Gebelikte Yaşanan Fiziksel Sağlık Sorunlarının İncelenmesi. Aile ve Toplum Eğitim- Kültür ve Araştırma Dergisi, 3, 35-42.

41. Yıldızeli Topçu, S. ve Yıldız Fındık, U. (2012).Effect of RelaxationExercise on ControllingPostoperativePain. Pain Management Nursing,13(1),11-17

42. Yılmaz, H. ve Tuncel D. (2014).Uyku Bozukluklarında Tedavi Rehberi. http://www.noroloji.org.tr/TNDData/Uploads/files/uyku\%20bozukluklar\%C4\%B1\%202014.pdf

43. Zafarghandi, N.,Hadavand, S., Davati, A., Mohseni, S.M., Kimiaiimoghadam, F. ve Torkestani, F. (2011). TheEffects of SleepQualityandDuration in LatePregnancy on LaborandFetalOutcome. Journal of Maternal-FetalandNeonatalMedicine, 8, 10-18. 